\title{
Frontiers in toxicogenomics - the grand challenge: to understand how the genome and epigenome interact with the toxic environment
}

\author{
Douglas Mark Ruden* \\ Department of Obstetrics and Gynecology, Wayne State University, Detroit, MI, USA \\ 2 C. S. Mott Center for Human Health and Development, Wayne State University, Detroit, MI, USA \\ ${ }^{3}$ Institute of Environmental Health Sciences, Wayne State University, Detroit, MI, USA \\ ${ }^{*}$ Correspondence: douglasr@wayne.edu
}

A recent advance that has revitalized toxicology studies in the past couple of decades is Frontiers in Genetics "toxicogenomics," the study of the effects of environmental toxins on global changes within a cell or tissue as related to genomic variables. "Transcriptional toxicogenomics" is the study of global gene expression patterns after administering a toxin. Similarly, "toxicoproteomics" is the study of global changes in protein levels or post-translational modifications; while "toxicometabolomics" is the study of global changes in metabolite levels after administering a toxin. A new field called "toxicoepigenomics" or more simply, the "epigenetics of toxicology," is the study of global epigenetic changes in a cell that are caused by exposure of a cell, tissue, or organism to a toxin or drug. Frontiers in Toxicogenomics provides a format for presenting cutting-edge reviews and studies in the frontiers of all branches of toxicogenomics.

One type of study within the area of transcriptional toxicogenomics called "genetical genomics" or "genetics of gene expression," is the combination of quantitative trait-locus (QTL) and wholegenome expression analyses (Brem et al., 2002; Broman, 2005). In genetical genomics, the investigator treats the expression of each of the $\sim 20,000$ genes in an organism as a quantitative trait and identifies cisexpression QTL (eQTL) in cis-regulatory sequences and trans-eQTL in trans-acting factors that regulate expression of co-regulated genes in specific pathways. Genetical toxicogenomics adds a new dimension to genetical genomics by studying the effects of an environmental toxin on global gene expression patterns (Ruden et al., 2009). Such studies are theoretically very powerful because they not only tell which genes are induced in a particular tissue (such as a brain region) by the toxin, but they also allow the identification of trans-acting factors and cis-acting sequences that are regulated by the toxin. Toxicogenetical genomic studies in mice have the advantage that thousands of recombinant inbred lines have recently been generated in a collaborative cross amongst eight different wild type strains of mice (Churchill et al., 2004). Rats are sometimes preferred models for toxicological screens because they have much larger organs than mice, allowing for easier gene and protein expression analyses because much more material can be obtained compared with mice. Recombinant inbred lines have also been developed in rats, and some laboratories have conducted genetical genomics and genetical toxicogenomics analyses in rats, especially in the rat brain.

The transcriptional toxicogenomic studies have mostly been done with recombinant inbred lines, such as in mice, C. elegans, and Drosophila, and utilized gene expression microarrays. However, next-generation sequencing technologies allow new types of transcriptional toxicogenomic studies to be conducted. For example, "speed QTL" analyses can be done by selecting a large population of model organisms for a particular trait, such as lifespan after feeding a toxin, for several generations and then sequencing the genome of the long-living descendents (Lai et al., 2007). The single nucleotide polymorphisms (SNPs) that are enriched in the long-living descendents are located in candidate toxin-survival genes which can be studied in follow up genetic and biochemical studies. Third generation sequencing technologies will soon make the "\$1000 genome" a reality and will not only allow "personalized medicine," which is using a person's genome sequence to optimize a drug regimen to treat a disease
(Ruden, 2007), but also "personalized toxicogenomics" which uses this genome information to determine a person's susceptibility to an environmental toxin.

Toxicoproteomics and toxicometabolimics are new areas that utilize stateof-the-art mass spectrometry and other sensitive assay systems that can quantify protein, peptide, and metabolic levels in a population of model organisms. Instead of gene expression being the quantitative trait, as in transcriptional toxicogenomics, protein, and metabolite levels can be used as quantitative traits. In this manner, protein QTL (pQTL) and metabolite-QTL (mQTL) can be identified in both cisand trans-genes that regulate the levels of molecules.

Toxicoepigenomics is the study of global epigenomic changes, such as DNA methylation changes, histone modifications, or microRNA changes, that are caused by exposure to toxins. In this manner, epigenetic-QTL (epiQTL) can be identified that identify cis- and trans-regulatory elements and factors that alter the epigenome in response to a toxin. It is known for instance that prenatal lead exposure causes hypomethylation of repeats in humans. It would be interesting to study global methylation patterns after exposure to lead and other toxins in large populations.

In conclusion, toxicogenomics is an exciting new field that has revitalized toxicology research. No longer need toxicologists study only LD50 values (lethal dose that kills $50 \%$ of the population) and use death alone as a toxicology endpoint. Now toxicologists can perform studies with much more subtle endpoints, such as gene expression, protein or metabolite levels, and epigenomic changes. Frontiers in Toxicogenomics provides a format for present research and reviews in this exciting new field. 


\section{REFERENCES}

Brem, R. B., Yvert, G., Clinton, R., and Kruglyak, L. (2002). Genetic dissection of transcriptional regulation in budding yeast. Science 296, 752-755.

Broman, K. W. (2005). Mapping expression in randomized rodent genomes. Nat. Genet. 37, 209-210. [Comment].

Churchill, G. A., Airey, D. C., Allayee, H., Angel, J. M., Attie, A. D., Beatty, J., Beavis, W. D., Belknap, J. K., Bennett, B., Berrettini, W., Bleich, A., Bogue, M., Broman, K. W., Buck, K. J., Buckler, E., Burmeister, M., Chesler, E. J., Cheverud, J. M., Clapcote, S., Cook, M. N., Cox, R. D., Crabbe, J. C., Crusio, W. E., Darvasi, A., Deschepper, C. F., Doerge, R. W., Farber, C. R., Forejt, J., Gaile, D., Garlow, S. J., Geiger, H., Gershenfeld, H., Gordon, T., Gu, J., Gu, W., de Haan, G., Hayes, N. L., Heller, C., Himmelbauer, H., Hitzemann, R., Hunter, K., Hsu, H. C., Iraqi, F. A., Ivandic, B., Jacob, H. J., Jansen, R. C., Jepsen, K. J., Johnson, D. K., Johnson, T. E., Kempermann, G., Kendziorski, C., Kotb, M., Kooy, R. F., Llamas, B., Lammert, F., Lassalle, J. M., Lowenstein, P. R., Lu, L., Lusis, A.,
Manly, K. F., Marcucio, R., Matthews, D., Medrano, J. F., Miller, D. R., Mittleman, G., Mock, B. A., Mogil, J. S., Montagutelli, X., Morahan, G., Morris, D. G., Mott, R., Nadeau, J.H., Nagase, H., Nowakowski, R. S., O’Hara, B. F., Osadchuk, A. V., Page, G. P., Paigen, B., Paigen, K., Palmer, A. A., Pan, H. J., Peltonen-Palotie, L., Peirce, J., Pomp, D., Pravenec, M., Prows, D. R., Qi, Z., Reeves, R. H., Roder, J., Rosen, G. D., Schadt, E. E., Schalkwyk, L. C., Seltzer, Z., Shimomura, K., Shou, S., Sillanpaa, M. J., Siracusa, L. D., Snoeck, H. W., Spearow, J. L., Svenson, K., Tarantino, L. M. Threadgill, D., Toth, L. A., Valdar, W., de Villena, F. P., Warden, C., Whatley, S., Williams, R. W., Wiltshire, T., Yi, N., Zhang, D., Zhang, M., and Zou, F.(2004). The collaborative cross, a community resource for the genetic analysis of complex traits. Nat. Genet. 36, 1133-1137.

Lai, C. Q., Leips, J., Zou, W., Roberts, J. F., Wollenberg, K. R., Parnell, L. D., Zeng, Z. B., Ordovas, J. M., and Mackay, T. F. (2007). Speed-mapping quantitative trait loci using microarrays. Nat. Methods 4 , 839-841.
Ruden, D. M. (2007). Personalized medicine and quantitative trait transcripts. Nat. Genet. 39, 144-145.

Ruden, D. M., Chen, L., Possidente, D., Possidente, B., Rasouli, P., Wang, L., Lu, X., Garfinkel, M. D., Hirsch, H.V., and Page, G. P. (2009). Genetical toxicogenomics in Drosophila identifies master-modulatory loci that are regulated by developmental exposure to lead. Neurotoxicology 30, 898-914.

Received: 17 January 2011; accepted: 23 February 2011; published online: 04 March 2011.

Citation: Ruden DM (2011) Frontiers in toxicogenomics - the grand challenge: to understand how the genome and epigenome interact with the toxic environment. Front. Gene. 2:12. doi: 10.3389/fgene.2011.00012

This article was submitted to Frontiers in Toxicogenomics, a specialty of Frontiers in Genetics.

Copyright $(2011$ Ruden. This is an open-access article subject to an exclusive license agreement between the authors and Frontiers Media SA, which permits unrestricted use, distribution, and reproduction in any medium, provided the original authors and source are credited. 